\title{
Resource use efficiency among maize farmers in Ghana
}

\author{
Dadson Awunyo-Vitor, Camillus Abawiera Wongnaa* and Robert Aidoo
}

\begin{abstract}
Background: Despite the enormous importance of maize in Ghana, maize farmers in the country continue to experience low yields, making Ghana self-insufficient in the production of the crop. For maize farmers to be helped to increase productivity, the focus should not only be on whether or not they have adopted productivity-enhancing technologies, but it is necessary to carefully examine whether they are even making maximum use of the technologies or inputs available to them. This study analysed resource use efficiency for Ghana's maize farms.

Methods: The data used were obtained through a cross-sectional survey of 576 maize farmers in the Northern Savannah, Transitional, Forest and Coastal Savannah zones of Ghana using structured questionnaire. Descriptive statistics, stochastic frontier analysis and the ratio of marginal value product to marginal factor cost were the methods of analysis employed.

Results: The results showed that generally, maize farmers in Ghana were inefficient in their use of resources available to them. Fertilizer, herbicide, pesticide, seed, manure and land were underutilized, while labour and capital were overutilized by the farmers. The results further showed that maize farmers in Ghana exhibit increasing returns to scale, indicating that the famers can increase their output by increasing the use of some of the key resources.

Conclusion: Incentives and strategies aimed at encouraging farmers to optimize the use of fertilizer, herbicide, pesticide, seed, manure and land are recommended to ensure improved maize productivity in Ghana. Currently, incentives and strategies could take the form of better management by government of the current fertilizer subsidy programme and efficient input distribution through farmer-based organizations to ensure easy access by farmers.
\end{abstract}

Keywords: Efficiency, Maize, Productivity, Resource use, Stochastic frontier

\section{Background}

Accounting for over $50 \%$ of total cereal production in Ghana, maize is the most important staple crop in the country. With a greater proportion of maize supply going into food consumption in Ghana, an increase in its productivity is undoubtedly crucial for achieving food security in the country. As a major constituent of livestock and poultry feed, the productivity and development of the poultry and livestock industries depend on the maize value chain. In the medium term, the demand for maize is expected to grow at an annual rate of $2.6 \%$ [18]. Despite the enormous importance of maize in Ghana, maize

\footnotetext{
*Correspondence: wongnaaa@yahoo.com

Department of Agricultural Economics, Agribusiness and Extension,

Kwame Nkrumah University of Science and Technology, Private Mail Bag,

University Post Office, Kumasi, Ghana
}

farmers in the country continue to experience low yields, making Ghana self-insufficient in the production of the crop [20]. For maize farmers to be helped to increase productivity, the focus should not only be on whether or not they have adopted productivity-enhancing technologies, but it is necessary to carefully examine whether they are even making maximum use of the technologies or inputs available to them. This will convince stakeholders in the maize subsector that the improved inputs they may have planned to introduce to the farmers will be utilized efficiently to help boost maize production in the country. Therefore, it is important to determine the efficiency of resource use in maize production in Ghana so that government and individuals interested in investing in maize production in Ghana will know the levels at which production inputs should be employed in order for them to 
achieve desired yields [30]. This is because apart from studies conducted by $[3,28]$ on resource use efficiency in maize production in Ghana, no other economic study has considered the subject in the country even though it has been done for other crops $[5,16,21,30,31]$, making literature on resource use efficiency in maize production in Ghana very limited. The findings of [3] showed that there was limited use of fertilizers, weedicides and improved seeds by maize farmers in the Asamankese district of Ghana. Also, the results of the work of [28] revealed that maize farmers in the Nkoranza area of Ghana overutilized labour and underutilized fertilizer and seeds.

However, resource use efficiency in maize production is common in other parts of the world, especially neighbouring Nigeria. Jirgi et al. [13] in a study on the profitability and resource use efficiency in maize production in Kontagora Local Government Area, Niger State, Nigeria, found that farm size, labour and fertilizer were overutilized, while capital inputs were underutilized. Gani and Omonona [8] studied the resource use efficiency among small-scale irrigated maize producers in Northern Taraba State of Nigeria. The empirical results showed that fertilizer, seeds, labour and land were underutilized, whereas water (the key variable) was overutilized. Taiwo et al. [29] also analysed the efficiency of resource use in hybrid and open-pollinated maize production in Giwa LGA of Kaduna State, Nigeria. The findings were that fertilizer and insecticides were underutilized, whereas seeds, labour and herbicides were overutilized. In a similar study, [15] conducted a study on the resource use efficiency in quality protein maize (QPM) production in Kaduna State, Nigeria. In this study, the results showed that whereas fertilizer, family and hired labour were overutilized, land and seeds were underutilized. The allocative efficiency analysis by [25] in a study on the resource use efficiency of maize (Zea mays L.) production in Sri Lanka showed that profitability can be increased by increasing land, seed and fertilizer as well as reducing use of agrochemicals and labour. The findings of the work of [2] in resource use efficiency in maize production under traditional and improved technology in Western Ethiopia revealed the mean technical, allocative and economic efficiencies under improved technology to be estimated at 74,82 and $61 \%$, respectively, while the corresponding results under the traditional technology were 92,80 and $73 \%$, respectively. Hasan [12] studied the economic efficiency and constraints of maize production in the northern region of Bangladesh and found that farmers in the study area had scope to increase maize productivity by attaining full efficiency through reallocating the resources. Zongoma et al. [32], studying resource use efficiency in maize production among small-scale farmers in Borno State in Nigeria, observed that maize production can be improved if resources like fertilizer, labour and farm size are adequately utilized. Sanusi et al. [27], in optimization of resource use efficiency in smallscale maize production in Niger State, Nigeria, reported underutilization of inputs such as land, improved seed, fertilizer and capital items.

Apart from the limited literature on the subject of resource use efficiency in maize production in Ghana, to the best of our knowledge, no study has analysed resource use efficiency in any crop at the national level for Ghana, making literature on resource use efficiency in agricultural production at the national level in Ghana limited. This article analyses the resource use efficiency of maize farmers in Ghana which is very important for policy makers in their design of policies aimed at improving resource use efficiency and consequently productivity in Ghana.

\section{Methods}

\section{Study area}

The study was conducted in the four main agro-ecological zones of Ghana, namely Northern Savannah, Transitional, Forest and Coastal Savannah zones. The Northern Savannah zone is located along the north-eastern corridor of the Northern Region with a total land area of about 125,430 $\mathrm{km}^{2}$. The tropical continental climate and Guinea Savannah vegetation type are seen in this area. The Transitional zone, which is located around the middle portion of the Brong-Ahafo Region and the northern part of Ashanti Region, covers a total land area of about $2300 \mathrm{~km}^{2}$. The climate of the place is the wet semi-equatorial type, while the vegetation is the Savannah woodland and a forest belt. The Forest zone, covering an area of about $135,670 \mathrm{~km}^{2}$, is floristically divided into rain forest and semi-deciduous forest. The climate of the place is the semi-equatorial type, while the vegetation is semideciduous forest zone with clay, sand and gravel deposits. The Coastal Savannah occupies about 20,000 $\mathrm{km}^{2}$ and comprises the Ho-Keta Plains, the Accra Plains and a narrow strip tapering from Winneba to Cape Coast.

\section{Data collection}

Farm-level primary data on maize production for the 2014 cropping season were collected from 576 maize farmers using structured questionnaire. The study used [4]'s sample size determination formula in the determination of the appropriate sample size. That is

$$
n=\frac{t^{2}(p)(q)}{d^{2}}
$$

where $n=$ sample size, $t=$ value for selected alpha level of 0.025 in each tail $=1.96, p=$ proportion of population engaged in maize production activities, $q=$ proportion of 
population who do not engage in maize production activities, and $d=$ acceptable margin of error for proportion being estimated $=0.05$.

According to the Ghana Living Standard Survey Report of the Fifth Round (GLSS 5), 41.5\% of households who harvested staple and/or cash crops in the last twelve months before September 2008 were maize farmers [9]. Assuming 95\% confidence level and 5\% margin of error, the sample size was calculated as follows:

$$
n=\frac{1.96^{2} \times 0.415 \times 0.585}{0.05^{2}}=373
$$

These procedures result in the minimum returned sample size. If a researcher has a captive audience, this sample size may be attained easily. However, since many educational and social research studies often use data collection methods such as surveys and other voluntary participation methods, the response rates are typically well below 100\%. Salkind [26] recommended oversampling by $40-60 \%$ to account for low response rate and uncooperative subjects. The sample size was therefore increased by $54.5 \%$ to correct all probable anomalies that might occur, increasing the sample size to 576 maize farmers.

Multi-stage sampling technique was employed in the study. Two districts/municipalities were purposively selected in the first stage from each agro-ecological zone based on total maize production by Ghana's districts/ municipalities [24]. The second stage consisted of random sampling of nine (9) villages from each of the sampled districts. Finally, the third stage comprised a random sample of eight (8) maize farmers from a list of maize farmers in each of the villages with the help of agricultural extension agents. The data collected consisted of detailed information on the socio-economic characteristics of the farmers, their inputs, outputs as well as prices of inputs and outputs.

\section{Data analysis}

Descriptive statistics were used to summarize the socioeconomic characteristics as well as quantities of inputs and outputs of the respondents. Also, the stochastic frontier production function was employed to analyse the determinants of maize output. Aigner et al. [1, 17] independently proposed the stochastic frontier production function. According to them, the stochastic frontier production function is defined by;

$$
\begin{aligned}
& y_{i}=f\left(x_{i} ; \beta\right)+e_{i} \quad \text { where } i=1,2, \ldots, N \\
& e_{i}=v_{i}-u_{i}
\end{aligned}
$$

where $y_{i}$ represents the level of output of the $i$ th maize farmer; $f\left(x_{i} ; \beta\right)$ is an appropriate production function of vector, $x_{i}$ of inputs for the $i$ th maize farmer and a vector, $\beta$ of parameters to be estimated. $e_{i}$ is an error term which comprises two components, $v_{i}$ and $u_{i}$. $v_{i}$ is a random error with zero mean, $N\left(0 ; \sigma^{2} v\right)$, and is specifically associated with random factors like measurement errors in production as well as weather factors that the maize farmer cannot control and it is assumed to be symmetric and independently distributed as $N\left(0 ; \sigma^{2} v\right)$, random variables and is independent of $u_{i}$. Conversely, $u_{i}$ is a non-negative truncated half normal, $N\left(0 ; \sigma^{2} v\right)$, random variable and is linked to farm-specific characteristics, which leads to the $i$ th maize farm not achieving maximum production efficiency. $u_{i}$ is therefore linked to the technical inefficiency of the maize farm and ranges from zero to one. However, $u_{i}$ may have other distributions like exponential and gamma. $N$ is the number of maize farmers that took part in the cross-sectional survey. Technical efficiency of a maize farmer is the ratio of observed output to the frontier output, given the quantity of resources employed by the farmer. Technical inefficiency therefore refers to the margin with which the level of output for the farmer falls below the frontier output.

$$
\text { Technical efficiency }=\mathrm{TE}_{i}=\frac{y_{i}}{y_{i}^{*}}
$$

where $y_{i}^{*}=f\left(x_{i} ; \beta\right)$, highest predicted value for the $i$ th farm

$$
\begin{aligned}
& \mathrm{TE}_{i}=\operatorname{Exp}\left(-u_{i}\right) \\
& \text { Technical inefficiency }=1-\mathrm{TE}_{i}
\end{aligned}
$$

The stochastic frontier production function can be estimated by the maximum likelihood estimation (MLE) technique. The technique makes use of the specific distribution of the disturbance term and is more efficient than corrected ordinary least squares [11]. Diagnostically, the generalized likelihood ratio test was used to determine whether the Cobb-Douglas or translog functional form fits the data collected from the maize farmers in this study better. The test allows evaluation of a restricted model with respect to an adopted model. The statistic associated with this test is defined as:

$$
\lambda=-2\left[\ln \frac{L\left(H_{0}\right)}{L\left(H_{1}\right)}\right]=-2\left[\ln L\left(H_{0}\right)-\ln L\left(H_{1}\right)\right]
$$

where $L\left(H_{0}\right)$ and $L\left(H_{1}\right)$ are the log-likelihood values of the adopted and the restricted models, respectively. The test statistic $\lambda$ has approximately a Chi-square distribution with a number of degrees of freedom equal to the number of parameters (restrictions), assumed to be zero in the null hypothesis. When $\lambda$ is lower than the corresponding critical value (for a given significance level), the null hypothesis cannot be rejected. The main 
hypothesis tested here is to find out whether the CobbDouglas functional form is an adequate representation of the maize production data collected, given the specification of the translog functional form. The test results showed that the translog functional form was more appropriate. Therefore, the translog functional form was adopted in this study. Theoretically, the stochastic frontier translog production function is specified as:

$$
\begin{aligned}
\ln y_{i}= & \beta_{0}+\sum_{k=1}^{m} \beta_{k} \ln x_{k i}+\frac{1}{2} \sum_{k=1}^{m} \sum_{j=1}^{m} \beta_{k j} \ln x_{k i} \ln x_{j i} \\
& +v_{i}-u_{i}
\end{aligned}
$$

where ln is natural logarithm, $y_{i}$ is total output, $x_{i}$ is vector of inputs, and $i j$ are positive integers $(i \neq j)$. $\beta$ is a vector of parameters to be estimated, and $v_{i}$ and $u_{i}$ have been defined above. The inefficiency model is also specified as:

$$
u_{i}=\delta_{0}+\sum_{m=1}^{N} \delta_{m} z_{i}
$$

where $z_{i}$ is a vector of farmer characteristics and $\delta$ is a vector of parameters to be estimated. STATA provides a joint estimation of the parameters in the stochastic frontier production function and those of variables in the inefficiency model as well as variance parameters. Empirically, the following stochastic frontier translog production function was estimated. implements in Ghథ; FET is quantity of fertilizer used in maize production, measured in kilogrammes per hectare $(\mathrm{kg} / \mathrm{ha}) ;$ MAN is quantity of manure used in maize production, measured in kilogrammes per hectare $(\mathrm{kg} / \mathrm{ha})$; PET is quantity of pesticides used in maize production, measured in litres per hectare (L/ha); and HEB is quantity of herbicides used in maize production, measured in litres per hectare (L/ha).

According to $[14,30]$, for maize farmers to be efficient in their use of production resources, their resources must be used in such a way that their marginal value product (MVP) is equal to their marginal factor cost (MFC) under perfect competition. Therefore, the resource use efficiency parameter was calculated using the ratio of MVP of inputs to the MFC. According to [7, 10], the efficiency of resource use is given as:

$$
r=\frac{\mathrm{MVP}}{\mathrm{MFC}}
$$

where $r=$ efficiency coefficient, MVP $=$ marginal value product, and MFC $=$ marginal factor cost of inputs.

$$
\mathrm{MFC}=P_{x}
$$

where $P_{x_{i}}=$ unit price of input, say $x$

$$
\mathrm{MVP}_{x}=\mathrm{MPP}_{x} \cdot P_{y}
$$

$$
\begin{aligned}
\ln \text { OUTPUT }_{i}= & \beta_{0}+\beta_{1} \ln \mathrm{SED}_{i}+\beta_{2} \ln \mathrm{FET}_{i}+\beta_{3} \ln \mathrm{PET}+\beta_{4} \ln \mathrm{MAN}_{i}+\beta_{5} \ln \mathrm{LAD}_{i} \\
& +\beta_{6} \ln \mathrm{LAB}_{i}+\beta_{7} \ln \mathrm{HEB}_{i}+\beta_{8} \ln \mathrm{CAP}+\beta_{9} \ln (\mathrm{SED})_{i}^{2}+\beta_{10} \ln (\mathrm{FET})_{i}^{2}+\beta_{11} \ln (\mathrm{PET})_{i}^{2} \\
& +\beta_{12} \ln (\mathrm{MAN})_{i}^{2}+\beta_{13} \ln (\mathrm{LAD})_{i}^{2}+\beta_{14} \ln (\mathrm{LAB})_{i}^{2}+\beta_{15} \ln (\mathrm{HEB})_{i}^{2}+\beta_{16} \ln (\mathrm{CAP})_{i}^{2} \\
& +\beta_{17}(\ln \mathrm{SED} \times \ln \mathrm{FET})_{i}+\beta_{18}(\ln \mathrm{SED} \times \ln \mathrm{PET})_{i}+\beta_{19}(\ln \mathrm{SED} \times \ln \mathrm{MAN})_{i} \\
& +\beta_{20}(\ln \mathrm{SED} \times \ln \mathrm{LAD})_{i}+\beta_{21}(\ln \mathrm{SED} \times \ln \mathrm{LAB})_{i}+\beta_{22}(\ln \mathrm{SED} \times \ln \mathrm{HEB})_{i} \\
& +\beta_{23}(\ln \mathrm{SED} \times \ln \mathrm{CAP})_{i}+\beta_{24}(\ln \mathrm{FET} \times \ln \mathrm{PET})_{i}+\beta_{25}(\ln \mathrm{FET} \times \ln \mathrm{MAN})_{i} \\
& +\beta_{26}(\ln \mathrm{FET} \times \ln \mathrm{LAD})_{i}+\beta_{27}(\ln \mathrm{FET} \times \ln \mathrm{LAB})_{i}+\beta_{28}(\ln \mathrm{FET} \times \ln \mathrm{HEB})_{i} \\
& +\beta_{29}(\ln \mathrm{FET} \times \ln \mathrm{CAP})_{i}+\beta_{30}(\ln \mathrm{PET} \times \ln \mathrm{MAN})_{i}+\beta_{31}(\ln \mathrm{PET} \times \ln \mathrm{LAD})_{i} \\
& +\beta_{32}(\ln \mathrm{PET} \times \ln \mathrm{LAB})_{i}+\beta_{33}(\ln \mathrm{PET} \times \ln \mathrm{HEB})_{i}+\beta_{34}(\ln \mathrm{PET} \times \ln \mathrm{CAP})_{i} \\
& +\beta_{35}(\ln \mathrm{MAN} \times \ln \mathrm{LAD})_{i}+\beta_{36}(\ln \mathrm{MAN} \times \ln \mathrm{LAB})_{i}+\beta_{37}(\ln \mathrm{MAN} \times \ln \mathrm{HEB})_{i} \\
& +\beta_{38}(\ln \mathrm{MAN} \times \ln \mathrm{CAP})_{i}+\beta_{39}(\ln \mathrm{LAD} \times \ln \mathrm{LAB})_{i}+\beta_{40}(\ln \mathrm{LAB} \times \ln \mathrm{HEB})_{i} \\
& +\beta_{41}(\ln \mathrm{LAD} \times \ln \mathrm{CAP})_{i}+\beta_{42}(\ln \mathrm{LAB} \times \ln \mathrm{HEB})_{i}+\beta_{43}(\ln \mathrm{LAB} \times \ln \mathrm{CAP})_{i} \\
& +\beta_{44}(\ln \mathrm{HEB} \times \ln \mathrm{CAP})_{i}+v_{i}-u_{i}
\end{aligned}
$$

where OUTPUT is output of maize, measured in kilogramme per hectare $(\mathrm{kg} / \mathrm{ha})$, and it is the dependent variable; SED is quantity of seed used, measured in kilogramme per hectare $(\mathrm{kg} / \mathrm{ha})$; LANDSZ is area of land cultivated with maize, measured in hectares; LAB is quantity of labour employed in maize production, measured in man-days; CAP is capital used in maize farm, measured as depreciated charges on farm tools and where $y=$ mean value of output, $x=$ mean value of input employed in the production of a product, $\mathrm{MPP}_{x}=$ marginal physical product of input $x$, and $P_{y}=$ unit price of maize output.

If $\beta_{x}=$ output elasticity of input $x$.

From the translog production function (Eq. 6),

$$
\beta_{x}=\frac{\partial \ln Y}{\partial \ln X}=\frac{\partial Y}{\partial x} \cdot \frac{x}{Y}
$$




$$
\operatorname{MPP}_{x}=\frac{\partial Y}{\partial x}=\beta_{x} \frac{Y}{x}
$$

$\operatorname{MPP}_{x}=$ marginal physical product of input $X$.

Therefore

$$
\mathrm{MVP}=\frac{\partial Y}{\partial X} \cdot P_{y}=\beta_{x} \frac{Y}{X} \cdot P_{y}
$$

Marginal value product (MVP) of a particular input is therefore calculated by the product of output elasticity of that input, the ratio of mean output to mean input values and the unit output price. On the other hand, marginal factor cost (MFC) of an input was obtained from the data collected on the unit price of that input. To decide whether or not an input was used efficiently, the following convention was followed in this study. If

$r=1$, it implies the input was used efficiently.

$r>1$, it implies the input was underutilized and therefore both output and profit would be increased if more of that input is employed.

$r<1$, it implies the input is overutilized and therefore both output and profit would be maximized if less of that input is employed [22].

Returns to scale were calculated by the sum of the output elasticities of the various inputs.

$$
\text { Returns to scale }=\sum_{i} \frac{\partial \ln Y}{\partial \ln X_{i}}=\sum_{i} \beta_{i}
$$

where $Y$ is output, $X_{i}$ are inputs and $\beta_{i}$ are output elasticities.

\section{Results}

\section{Descriptive analysis}

Table 1 presents the socio-economic characteristics of maize farmers interviewed in the study. Table 2 also presents the descriptive statistics of farmers' characteristics and quantities of inputs used and outputs obtained. The results showed that $77.4 \%$ of maize farmers in the sample are males, while $22.6 \%$ are females. The ages of the respondents ranged from 18 to 78 years with a mean age of 45.2 years (Table 2). Also, Table 1 shows that majority of the respondents (56.9\%) are within the age bracket of 18-45 years. The results of educational level of the farmers presented in Table 1 show that $35.9 \%$ of maize farmers interviewed received no formal education and $34.7 \%$ got to middle school, junior secondary school (JSS) or junior high school (JHS). Table 2 also shows that, on average, maize farmers in Ghana have 6 years of schooling.

For the sampled maize farmers who had access to

\begin{tabular}{|c|c|c|}
\hline Variable & Frequency & $\%$ \\
\hline \multicolumn{3}{|l|}{ Sex } \\
\hline Male & 446 & 77.4 \\
\hline Female & 130 & 22.6 \\
\hline Total & 576 & 100 \\
\hline \multicolumn{3}{|l|}{ Age group (years) } \\
\hline $18-45$ & 328 & 56.9 \\
\hline $46-60$ & 180 & 31.2 \\
\hline Greater than 60 & 68 & 11.8 \\
\hline Total & 576 & 100 \\
\hline \multicolumn{3}{|l|}{ Educational level } \\
\hline No formal education & 207 & 35.9 \\
\hline Primary school & 84 & 14.6 \\
\hline Middle school/JSS/JHS & 200 & 34.7 \\
\hline SSS/SHS & 69 & 12 \\
\hline Training college/tertiary & 16 & 2.8 \\
\hline Total & 576 & 100 \\
\hline \multicolumn{3}{|l|}{ Association membership } \\
\hline No & 436 & 75.7 \\
\hline Yes & 140 & 24.3 \\
\hline Total & 576 & 100 \\
\hline \multicolumn{3}{|l|}{ Access to credit } \\
\hline No & 475 & 82.5 \\
\hline Yes & 101 & 17.5 \\
\hline Total & 576 & 100 \\
\hline
\end{tabular}
extension service, the average number of times extension
Table 1 Socio-economic characteristics of maize farmers

Source: Survey, 2015

agents visited them was calculated to be 3 times (Table 2). Also $75.7 \%$ of maize farmers in the sample did not belong to any farmer association as against $24.3 \%$ that were members of farmer associations (Table 1). In fact, most of the respondents considered in this study had no maize production credit from any financial source, be it formal or informal. For example, $82.5 \%$ of the farmers never received credit from any financial source. With a mean of 7.61, the household size ranged from 2 to 34 (Table 2). Also, Table 2 shows that on average, the respondent farmers had 14.07 number of years of experience in maize farming. The mean maize output recorded in the study was $1.8 \mathrm{Mt} / \mathrm{ha}$, and the mean quantity of labour used was 69.07 man-days. Finally, the mean farm size cultivated was estimated to be 2.862 ha.

\section{Appropriateness of stochastic frontier translog production function}

The results of the generalized likelihood ratio test for data collected from the study area showed that at least one of the interaction terms is statistically different from zero (Table 3). Table 4 also presents the variance parameters for the stochastic frontier production function for 
Table 2 Descriptive statistics of farmers' characteristics and quantities of inputs and outputs

\begin{tabular}{lllll}
\hline Variable & Minimum & Maximum & Mean & $\begin{array}{l}\text { Standard } \\
\text { deviation }\end{array}$ \\
\hline Age (years) & 18 & 78 & 45.15 & 11.61 \\
Education (years) & 0 & 18 & 5.96 & 4.976 \\
Experience (years) & 1 & 50 & 14.07 & 10.83 \\
Farm size (ha) & 0.2 & 70 & 2.862 & 12.71 \\
Number of plots & 0.4 & 50 & 1.579 & 2.164 \\
Extension visits & 0 & 26 & 2.727 & 4.833 \\
Fertilizer (kg/ha) & 0 & 225 & 125 & 190 \\
Herbicide (L/ha) & 0 & 12.5 & 5.164 & 7.445 \\
Pesticide (L/ha) & 0 & 11 & 0.111 & 0.889 \\
Seed (kg/ha) & 15 & 24 & 18 & 17 \\
Labour (man-days/ha) & 9 & 1096 & 69.07 & 97.16 \\
Manure (kg/ha) & 0 & 625 & 29.25 & 272.7 \\
Capital (Ghc) & 40 & 2500 & 558 & 766 \\
Size of household & 2 & 34 & 7.611 & 4.719 \\
Output (Mt/ha) & 0.01 & 2.03 & 1.8 & 1.2 \\
\hline
\end{tabular}

Source: Survey, 2015

Table 3 Results of hypotheses test for the model used

\begin{tabular}{lllll}
\hline Restriction & $\boldsymbol{L}\left(\boldsymbol{H}_{\mathbf{0}}\right)$ & $\boldsymbol{\lambda}$ & $\boldsymbol{X}^{\mathbf{2}}$ & Decision \\
\hline$H_{0}: \beta_{i j}=0$ & -98.2 & 38.2 & 23.3 & Rejected \\
$\delta_{m}=0$ & -148.7 & 28.4 & 10.1 & Rejected \\
\hline
\end{tabular}

Critical values are at $5 \%$ significance level and are obtained from $x^{2}$ distribution table. $L\left(H_{0}\right)=$ log-likelihood function, $\lambda=$ test statistic, $\beta_{i j}=$ parameters in the square and cross terms and $\delta_{m}=$ parameters in the inefficiency term

Table 4 Variance parameters for the stochastic frontier production function

\begin{tabular}{lll}
\hline Variable & Parameter & Standard error \\
\hline Sigma squared $\sigma^{2}=\sigma_{u}^{2}+\sigma_{v}^{2}$ & $0.72206^{*}$ & 0.006 \\
Gamma $\gamma=\sigma_{u}^{2} / \sigma^{2}$ & $0.999999^{* * *}$ & 0.046 \\
Lambda $\lambda=\sigma_{u} / \sigma_{v}$ & $3,764,018^{* * *}$ & 0.009 \\
Log-likelihood & -246.316 & \\
Number of farmers & 548 & \\
Wald & $3.1 \times 10^{10 * * *}$ & \\
Mean VIF & 1.2519 & \\
Breusch-Pagan stat & 0.5664 & \\
\hline
\end{tabular}

Source: Survey, 2015

The asterisks indicate levels of significance. ${ }^{* *}$ is significant at $1 \%,{ }^{* *}$ is significant at $5 \%$, and ${ }^{*}$ is significant at $10 \%$

maize farmers in the sample. The values of $\gamma(0.999999), \lambda$ $(3,764,018)$ and $\sigma^{2}(0.72206)$ for the study are quite high and significant at 1,1 and $10 \%$, respectively (Table 4 ). The
Wald Chi-square statistic $\left(3.1 \times 10^{10}\right)$ for the study is significant at the $1 \%$ level. Also, the mean variance inflation factor (VIF) calculated was small and the Breusch-Pagan (BP) test was not significant.

\section{Determinants of output and resource use efficiency by maize farmers in Ghana}

The results of the stochastic frontier translog production function analysis for maize farmers revealed that whereas fertilizer, herbicides, pesticides and land inputs had significant positive effects on the output of maize, labour input had a significant negative sign (Table 5). Table 6 also presents the production elasticities of these inputs. The elasticities are $0.485,0.177,0.003,1.145$ and 0.245 for fertilizer, herbicide, pesticide, land and labour inputs, respectively. Also, the return to scale calculated for the respondents was 3.327 (Table 6). Considering the technologies available to farmers as well as inputs and output prices, resource use efficiency was determined at the level where marginal value product (MVP) was equal to marginal factor cost (MFC). That is, a resource is efficiently utilized if its marginal value product and marginal factor cost are the same. Table 6 presents the ratios of the MVP to MFC for the maize farmers interviewed. The results revealed that the ratios were greater than unity (1) for fertilizer, herbicide, pesticide, seed, manure and farm size. The ratios for labour and capital were, however, found to be less than unity. The adjustments in marginal value products (MVPs) for optimal resource use (\% divergence) by the maize farmers presented in Table 7 show that, for resources to be efficiently utilized, more than $70.3 \%$ increase in fertilizer, $89.6 \%$ rise in herbicide, $86 \%$ increase in pesticide, $94.7 \%$ increase in seed, $99.9 \%$ increase in manure and $97.2 \%$ increase in farm size would be required. On the other hand, quantities of labour and capital would be expected to decline by 20.8 and $81.7 \%$, respectively.

\section{Discussion}

It could be inferred from the results on gender distribution of the respondents that maize production in Ghana is dominated by males. This could be attributed to the crucial roles women performed in the domestic and economic life of society which reduced the time available for maize production. This comprises the unmeasured non-economic activities, such as child care, cooking and cleaning, performed by females in the household. This finding corroborates those of earlier studies [3, 32] and implies that, generally, maize production is dominated by males. The age distribution and the mean age also show that the sampled maize farmers are relatively young. This condition may have a positive influence on the efficiency of input utilization in maize production. 
Table 5 Maximum likelihood estimates of stochastic frontier production function

\begin{tabular}{|c|c|c|c|c|c|}
\hline Variable & Coefficient & Standard error & Variable & Coefficient & Standard error \\
\hline Constant & 6.141105 & & In PET $\times$ In CAP & $0.0054^{* * *}$ & 0.00166 \\
\hline In FET & $0.035808^{*}$ & 0.019983 & In PET $\times$ In HEB & $-0.032^{* * *}$ & 0.00901 \\
\hline In HEB & $0.28478^{* * *}$ & 0.083703 & $\ln \mathrm{SED} \times \ln \mathrm{LAB}$ & $-0.0435^{* *}$ & 0.020435 \\
\hline In PET & $0.009152^{* *}$ & 0.00412 & In SED $\times$ In MAN & -0.011104 & 0.019845 \\
\hline In SED & 0.025144 & 0.016284 & $\ln S E D \times \ln L A D$ & $-0.164^{* * *}$ & 0.034314 \\
\hline $\ln L A B$ & $-0.2874^{* * *}$ & 0.076363 & $\ln \mathrm{SED} \times \ln \mathrm{CAP}$ & -0.005622 & 0.007020 \\
\hline In MAN & -0.0047556 & 0.004164 & In SED $\times$ In HEB & $0.0464^{* * *}$ & 0.01499 \\
\hline In LAD & $0.72564^{* * *}$ & 0.14299 & $\ln \angle A B \times \ln M A N$ & $0.0258^{* * *}$ & 0.008313 \\
\hline In CAP & -0.04421 & 0.030529 & $\ln \angle A B \times \ln \angle A D$ & 0.0408982 & 0.015034 \\
\hline $\ln$ FET $\times \ln$ FET & $-0.0075^{* * *}$ & 0.001945 & $\ln \angle A B \times \ln C A P$ & -0.009154 & 0.009142 \\
\hline In PET × In PET & 0.008695 & 0.017164 & $\ln \angle A B \times \ln H E B$ & $-0.104^{* * *}$ & 0.010646 \\
\hline In HEB $\times$ In HEB & $-0.0376^{* * *}$ & 0.011096 & In MAN $\times$ In LAD & $0.0119^{* * *}$ & 0.022958 \\
\hline In SED $\times$ In SED & $-0.0975^{* * *}$ & 0.00871 & $\ln M A N \times \ln C A P$ & 0.0020805 & 0.002654 \\
\hline $\ln \angle A B \times \ln \angle A B$ & $-0.01556^{* *}$ & 0.00757 & In MAN $\times \ln H E B$ & $0.01491^{* *}$ & 0.005952 \\
\hline In MAN $\times$ In MAN & $-0.00523^{* *}$ & 0.002116 & In $L A D \times \ln C A P$ & 0.0130063 & 0.008294 \\
\hline $\ln L A D \times \ln L A D$ & 0.017689 & 0.02085 & In LAD $\times$ In HEB & $-0.006^{* * *}$ & 0.001830 \\
\hline $\ln C A P \times \ln C A P$ & $-0.0099^{* * *}$ & 0.00264 & In CAP $\times \ln$ HEB & -0.004569 & 0.001371 \\
\hline In FET × In PET & $0.03589^{* * *}$ & 0.010018 & In FET $\times$ In CAP & -0.002860 & 0.002089 \\
\hline In FET $\times$ In HEB & -0.002079 & 0.00348 & In PET $\times$ In SED & $-0.0037^{* *}$ & 0.001425 \\
\hline $\ln$ FET $\times \ln$ SED & 0.006614 & 0.005298 & $\ln P E T \times \ln L A B$ & 0.0005474 & 0.000422 \\
\hline $\ln F E T \times \ln L A B$ & -0.003543 & 0.002891 & In PET $\times$ In MAN & 0.0056727 & 0.006087 \\
\hline In FET × In MAN & $-0.00449^{* *}$ & 0.002187 & In PET × In LAD & 0.0008757 & 0.003021 \\
\hline In FET x In LAN & $0.002772^{* *}$ & 0.002519 & & & \\
\hline
\end{tabular}

Source: Survey, 2015

The asterisks indicate levels of significance. ${ }^{* * *}$ is significant at $1 \%,{ }^{* *}$ is significant at $5 \%$, and ${ }^{*}$ is significant at $10 \%$

Table 6 Input elasticities and ratio of marginal value product to marginal factor cost

\begin{tabular}{llllll}
\hline Variable & Elasticity & MPP & MVP & MFC & $\boldsymbol{r}$ \\
\hline Fertilizer & 0.485 & 3.8 & 3.7 & 1.1 & 3.4 \\
Herbicide & 0.177 & 94.4 & 91.6 & 9.5 & 9.6 \\
Pesticide & 0.003 & 74.4 & 72.2 & 10.1 & 7.1 \\
Seed & 0.734 & 54.1 & 52.5 & 2.8 & 18.7 \\
Labour & 0.245 & 9.8 & 9.5 & 12 & 0.79 \\
Manure & 0.045 & 193 & 187 & 0.01 & 15,558 \\
Land & 1.145 & 1101 & 1068 & 30.4 & 35.2 \\
Capital & 0.493 & 2.43 & 2.36 & 12.9 & 0.18 \\
\hline
\end{tabular}

Source: Survey, 2015

$\mathrm{MPP}=$ marginal physical product, $\mathrm{MVP}=$ marginal value product,

MFC $=$ marginal factor cost,$r=$ efficiency coefficient, scale elasticity $=3.327$

This could be the result of the believe that young farmers easily accept new agricultural technologies and innovations thereby making them use appropriate input mix in their production. This is similar to the finding on age distribution by [3] that reported that majority of maize farming population are below 40 years. According to the
Table 7 Adjustments in MVPs for optimal resource use (\% divergence)

\begin{tabular}{lcl}
\hline Variable & Efficiency gap & $\begin{array}{l}\text { \% divergence } \\
\text { from optimal levels }\end{array}$ \\
\hline Fertilizer & 2.6 & 70.3 \\
Herbicide & 82.1 & 89.6 \\
Pesticide & 62.1 & 86 \\
Seed & 49.7 & 94.7 \\
Labour & 2.5 & 20.8 \\
Manure & 186.69 & 99.9 \\
Land & 1037.6 & 97.2 \\
Capital & 10.54 & 81.7 \\
\hline
\end{tabular}

Source: Survey, 2015

study, the young farming population may have positive implications on productivity because it is believed that the younger the farming population, the more productive the labour is and consequently higher outputs are obtained. The results on education compare well with the findings of [32] that also reported a $37.4 \%$ lack of formal education among small-scale maize farmers in Nigeria. 
The implication is that some level of inefficiency in input utilization is possible among maize farmers since education is expected to have a positive effect on efficiency [28]. With high levels of farming experience, the productivities and efficiencies of maize farmers in Ghana are expected to be on the higher side since experienced farmers could predict appropriate husbandry practices for efficient maize production. The high level of farming experience is expected as it is in line with the findings of [32] that also reported that $80.9 \%$ of the sampled maize farmers have at least 11 years of experience. The finding on access to agricultural extension service by the farmers is an indication of poor provision of extension service to the farmers. This may prevent farmers from using their resources efficiently. The few number of farmers that joined farmer-based organizations could have an adverse effect on the resource use efficiency of maize production in the study area since extension agents normally disseminate information on good agricultural practices through farmer-based organizations. Poor access to credit by the respondent farmers is a potential source of resource use inefficiency in maize production since credit allows farmers to acquire efficiency-enhancing inputs such as fertilizer, labour, pesticides and herbicides. With maize production being a labour-intensive activity, the results on household size show that the respondents have some source of labour which could enhance their resource use efficiencies. The results on maize yield imply that average maize yield for the farmers is relatively lower than the estimated potential yield of $6.0 \mathrm{Mt} / \mathrm{ha}$ for Ghana [19]. The relatively small farm sizes recorded in the study imply that most maize production activities in Ghana are on a small scale.

The significance of the likelihood ratio test makes the translog production function an appropriate fit for the data, and therefore, the rather popular but inflexible Cobb-Douglas functional form should be rejected. The high $\gamma$ value for maize farmers in the study area indicates the presence of technical inefficiencies among the sampled farmers, making the stochastic frontier production function an appropriate model for the study. The value of $\lambda$ shows that the one-sided error term $U$ dominates the symmetric error term $V$, so variation in actual maize output comes from differences in farmers' specific factors rather than random variability, hence the need for the inclusion of an inefficiency term in the production function and hence once again the appropriateness of the stochastic frontier production function for this study. Also, the significance of the values of $\lambda$ and $\sigma^{2}$ implies good fit and the correctness of the specified distributional assumption. The Wald Chi-square results also show that the model was jointly significant and that the inputs jointly explain the variations in maize output. The small mean VIF indicates the absence of multicollinearity in the model [6], and also, the insignificance of the BreuschPagan (BP) test reveals safety of heteroskedasticity.

For maize farmers in the study area, the elasticity values show that a $1 \%$ rise in the levels of fertilizer, herbicide, pesticide and land has the effect of increasing output levels by $0.485,0.177,0.003$ and $1.145 \%$, respectively. This finding corroborates the results of $[10,22]$. However, the significant negative effect of labour could be the result of excess labour supply by the farm household.

The returns to scale calculated for maize farmers in the study area reveal increasing returns to scale for the farmers which imply that maize production in Ghana during the 2014 rainy season was in stage one of the production function. The results suggest that maize farmers in Ghana could enlarge their production scale by about $3.3 \%$ on average, in order to adequately expand productivity, given their disposable resources. That is, Ghanaian maize farmers can increase their maize output by employing more of the resources (fertilizer, herbicide, pesticide, seed, labour, land, manure and capital) employed in maize production. This finding is in agreement with the results of some studies on resource use efficiency in maize production in Ghana and other parts of the world [3, 27-29], even though it disagrees with the findings of [23].

The marginal productivities revealed that maize farmers in the study area utilized land more efficiently vis-àvis the other resources. This suggests that if more lands were cultivated, it would have led to an increase in maize output by $1101 \mathrm{~kg}$ among the farmers in the study area. This result is in line with the findings of similar studies conducted by [3, 25, 27-29, 32].

The results on resource use efficiency for maize farmers in the study area suggest that the farmers were not efficient in the allocation of any of the resources available to them. That is, fertilizer, herbicide, pesticide, seed, manure and land were underutilized, while labour and capital (farm tools) were overutilized. Maize output in Ghana could therefore increase if more of such inputs like fertilizer, herbicide, pesticide, seed, manure and land were employed, while quantities of labour and capital were reduced. The aforementioned results are also in consonance with the results obtained by similar studies on resource use efficiency in maize production conducted in Ghana and other countries [3, 25, 27-29, 32]. The results on divergence from optimal levels of resource use show great divergence from optimal levels of use of manure (underutilized) than any other input. This is followed closely by divergence from optimal levels of use of land. Sienso et al. [25, 27, 28, 32] obtained similar results in their resource use efficiency studies in maize production. 


\section{Conclusion}

Generally, for optimal use of resources in maize production in Ghana, quantities of fertilizer, herbicide, pesticide, seed, manure and land should be increased while labour as well as capital (farm tools and equipments) should be reduced. Incentives and strategies aimed at encouraging farmers to use more fertilizer, herbicide, pesticide, labour, manure and land are recommended for resource use efficiency to be achieved by the farmers. Currently, incentives and strategies could take the form of better management by government of the current fertilizer subsidy programme and efficient input distribution through farmer-based organizations to ensure easy access by farmers. Also, extension officers should encourage maize farmers to join farmer-based organizations (FBOs) in places where there are established ones by presenting to the farmers the benefits of joining such organizations. In places where there are no established ones, extension officers should assist maize farmers to team up and form such organizations. This is because information on agricultural technologies and the right input mix is normally disseminated through farmer associations, and therefore, farmers who belong to such associations will more likely have knowledge of suggested technologies and appropriate input mix than those who are not members of such associations. The Agricultural Development Bank (ADB) should also live up to its mandate to ensure easy acquisition of loans by farmers. Acquired loans will be used to purchase required production inputs. Farmers, especially those in farmer-based organizations, are also encouraged to form their own informal credit schemes with which they can help one another.

\section{Abbreviations \\ BP: Breusch-Pagan; FBO: farmer-based organizations; GLSS: Ghana Living Standards Survey; GSS: Ghana Statistical Service; JHS: junior high school; JSS: junior secondary school; MFC: marginal factor cost; MPP: marginal physical product; MVP: marginal value product; MLE: maximum likelihood estima- tion; MiDA: Millennium Development Authority; MOFA: Ministry of Food and Agriculture; SRID: Statistics, Research and Information Directorate; VIF: variance} inflation factor.

\section{Authors' contributions \\ DAV was responsible for designing the study and data collection. CAW conceived the idea and was responsible for analysis of the data as well as preparation of the manuscript. RA provided technical advice in formulation of the research objectives and the review of the manuscript. All authors read and approved the final manuscript.}

\section{Acknowledgements}

We are especially indebted to the staff of the Ministry of Food and Agriculture in the West Mamprusi, East Gonja, Nkoranza, Ejura Sekyedumase, Fanteakwa, Sekyere South, Gomoa and Ketu districts/municipalities of Ghana for the information they provided about the maize crop and also assisting in the data collection. We are also grateful to the respondent maize farmers in the aforementioned districts/municipalities without whose cooperation the study could not have taken place.

\section{Competing interests}

The authors declare that they have no competing interests.

Received: 15 October 2016 Accepted: 2 December 2016

Published online: 21 December 2016

\section{References}

1. Aigner DK, Lovell CK, Schmidt P. Formulation and estimation of stochastic frontier production function models. J Econom. 1977;6:21-37.

2. Alene A. Resource use efficiency in maize production under traditional and improved technology in Western Ethiopia. In: Proceedings of the conference: challenges to organic farming and sustainable land use in the tropics and sub-tropics. Centre for International Rural Development, Deutscher Tropentag; 2002. p. 9-11.

3. Amankwah CYG. The structure and efficiency in resource use in maize production in the Asamankese District of Ghana. Doctoral dissertation, University of Ghana; 1996.

4. Bartlett JE, Kotrlik IJW, Higgins CC. Organisational research: determining the appropriate sample size in survey research. Inf Technol Learn Perform J. 2001;19(1):43-50.

5. Danso-Abbeam G, Dahamani AM, Bawa GA. Resource-use-efficiency among smallholder groundnut farmers in Northern Region, Ghana. Am J Exp Agric. 2015;6(5):290.

6. Edriss AK. A passport to research methods. Las Vegas: International Publishers and Press; 2003.

7. Fasasi AR. Resource use efficiency in yam production in Ondo State, Nigeria. Agric J. 2006;1(2):36-40

8. Gani BS, Omonona BT. Resource use efficiency among small-scale irrigated maize producers in Northern Taraba State of Nigeria. J Hum Ecol. 2009;28(2):113-9.

9. GSS (Ghana Statistical Service). Report on the fifth round of Ghana living standards survey (GLSS 5). Accra: Ghana Statistical Service; 2008.

10. Goni M, Mohammed S, Baba BA. Analysis of resource-use efficiency in rice production in the Lake Chad area of Borno State, Nigeria. J Sustain Dev Agric Environ. 2007;3(2):31-7.

11. Greene WH. Econometric analysis. New York: Pearson Education; 2005.

12. Hasan MF. Economic efficiency and constraints of maize production in the northern region of Bangladesh. J Innov Dev Strategy. 2008;2(1):18-32.

13. Jirgi AJ, Ibrahim FD, Tanko L, Lawal M. Profitability and resource use efficiency in maize production in Kontagora local government area, Niger State, Nigeria. J Agric For Soc Sci. 2007;5(2). doi:10.4314/joafss.v5i2.46710

14. Kabir Miah MA, Ashraful Alam AKM, Rahman AHMA. Impact of agricultural credit on MV Boro Rice cultivation in Bangladesh. J Agric Rural Dev. 2006;4(1):161-8.

15. Kehinde FT, Olukosi JO, Ala AL, Maikasuwa MA, Odunsi AA. Determination of the level of resource-use efficiency in quality protein maize (QPM) production in Kaduna State, Nigeria. Int J Appl Agric Apic Res. 2012;8(1):24-30.

16. Kuwornu JKM, Amegashie DPK, Wussah CE. Productivity and resource use efficiency in tomato and watermelon farms: evidence from Ghana. Dev Ctry Stud. 2012;2(2):23-37.

17. Meeusen W, Van den B. Efficiency estimation from Cobb-Douglas production functions with composed error. Int Econ Rev. 1977;18:435-44.

18. MiDA (Millennium Development Authority). Investment opportunity in Ghana: maize, rice, and soybean. Accra: MiDA; 2010.

19. MOFA (Ministry of Food and Agriculture). Agriculture in Ghana: facts and figures statistics, research and information directorate (SRID). Accra: MiDA; 2010.

20. MOFA (Ministry of Food and Agriculture). Agriculture in Ghana: facts and figures statistics, research and information directorate (SRID). Accra: MiDA; 2012.

21. Nimoh F, Asuming-Brempong S. Resource use efficiency for cowpea production in Akatsi District of Ghana. Asian J Agric Rural Dev Econ Financ Rev. 2012;2(1):55-61.

22. Ohajianya DO. Resource use efficiency of land owners and tenants in food crop production in Imo State Nigeria. J Sustain Trop Agric Res. 2006;17:26-30 
23. Okon ET. Comparative analysis of large and small scale farmers resource use efficiency in food crop production in Akwa-lbom State, Nigeria. J Agric Food Sci. 2005;3(1):75-84.

24. Ragasa C, Dankyi A, Acheampong P, Wiredu AN, Chapoto A, Asamoah M Tripp R. Patterns of adoption of improved maize technologies in Ghana. Ghana Strategy Support Program, International Food Policy Research Institute (IFPRI), Working Paper 36; 2013.

25. Rupasena LP, Khan Jl. Resource use efficiency of maize (Zea mays L.) production in Mahawali "H" area. In: 6th annual research symposium, Sri Lanka; 2014.

26. Salkind NJ. Exploring research. 3rd ed. Upper Saddle River: Prentice Hall; 1997.

27. Sanusi SM, Ogungbile AO, Yakasai MT, Ahmad MM, Daneji MI. Optimization of resource use efficiency in small scale maize production in Niger State, Nigeria. Asian J Sci Technol. 2015;6(2):1070-5.

28. Sienso G, Asuming-Brempong S, Amegashie DPK. Estimating the efficiency of maize farmers in Ghana. Contributed paper prepared for presentation at the 4th international conference of the AAAE, Cape Town, Hammamet, Tunisia, 22-25 September 2013; 2013.
29. Taiwo BA, Omolehin RA, Ibrahim U. Efficiency of resource use in hybrid and open-pollinated maize production in Giwa LGA of Kaduna State, Nigeria. Am J Exp Agric. 2011;1(3):86-95.

30. Tambo JA, Gbemu T. Resource-use efficiency in tomato production in the Dangme West District, Ghana. In: Conference on international research on food security, natural resource management and rural development, Tropentag. ETH Zurich; 2010.

31. Wongnaa CA, Ofori D. Resource-use efficiency in cashew production in Wenchi Municipality, Ghana. AGRIS Online Pap Econ Inform. 2012;4(2):73-80.

32. Zongoma BA, Bulama YM, Shettima BG, Umar ASS. Resource use efficiency in maize production among small-scale farmers in Biu local government area, Borno State Nigeria. J Resour Dev Manag. 2015;10:2422-8397.

\section{Submit your next manuscript to BioMed Central and we will help you at every step:}

- We accept pre-submission inquiries

- Our selector tool helps you to find the most relevant journal

- We provide round the clock customer support

- Convenient online submission

- Thorough peer review

- Inclusion in PubMed and all major indexing services

- Maximum visibility for your research

Submit your manuscript at www.biomedcentral com/submit 